\title{
Effects of Beta-lactoglobulin Gene Polymorphism and Some Factors on Milk Quality and Yield in Dairy Cattle of Kashmir, India
}

Ruksana M. Shah', N.A. Ganai², F.D. Sheikh ${ }^{3}$, H.M. Khan ${ }^{4}$, S. Shanaz', Safeer Alam ${ }^{1}$, Nusrat N. Khan ${ }^{1}$, Mir Shabir', Saba Bukhari', Ambreen Hamadani', Mubashir A. Rather ${ }^{6}$

10.18805/ajdfr.DR-1700

\begin{abstract}
Background: Polymorphisms in candidate beta-lactoglobulin genes are associated with traits of economic importance in cows and are related to milk composition, quality, production as well as cheese-production. The objective of the study was to evaluate the effects of breed, season and polymorphism on milk quality and yield in Jersey and Crossbred Holstein Friesian cows.

Methods: The quality traits studied were fat \%, lactose \%, protein \%, SNF, density and ash while quantity traits were average monthly milk yield, protein yield and fat yield. The beta-lactoglobulin gene exon IV (262 bp) was screened for polymorphisms by PCR-RFLP using BsuRI (Hae III) enzyme.

Result: Our investigation revealed only two patterns $A A$ and $A B$ in both the breeds under study. $B B$ genotype was absent. $A A$ genotype was most abundant in Jersey cows (0.68) and crossbred HF cows (0.56). A allele frequency was highest in Crossbred HF cows (0.72) and Jersey cows (0.66). In Jersey genotype $A B$ was observed to be responsible for high milk yield, protein and fat yield in each season whereas it was genotype AA of crossbred HF cows affecting milk yield, protein and fat yield. In crossbred HF cow, genotype effect was observed to be non-significant $(p>0.05)$ on all quality traits and effect of season was significant on lactose $\%$ and fat \%. In Jersey cows, genotype and season effects were significant $(P<0.05)$ on fat \% concluding that the breed, season and genotype affectmilk quality and yield.
\end{abstract}

Key words: Beta-lactoglobulin gene, Breed, Genotype, Milk quality, Season, Yield.

\section{INTRODUCTION}

Milk is an important source of essential nutrients for lactating calves and a key raw material for human food preparations (Reinhardt et al., 2012). All over the world people fulfil approximately $13 \%$ of their protein requirement from milk and milk products. Bovine milk proteins are generally classified as caseins, which make up about $80 \%$ of the milk proteins, consisting of four proteins: Alpha S1 (CSN1S1, $39-46 \%$ of total caseins), alpha S2 (CSN1S2, 8-11\%), beta (CSN2, 25-35\%) and kappa (CSN3, 8-15\%) (Eigel et al., 1984). Whey proteins make about $16 \%$ of the total milk protein and contain two major proteins alpha lactalbumin and beta lactoglobulin. Other minor part is made by peptones/low molecular weight peptides (3\%) and milk fat globule membrane (MFGM) proteins (1\%) (D'Alessandro et al., 2011). Ruminant's milk proteins are coded by highly polymorphic genes, containing an unusually large number of polymorphisms (Nilsen et al., 2009). A chain of studies continued and according to a recent review by Caroli et al. (2009) of milk protein variants, 9 as1 - CN (A, B, C, D, E, F, $G, H, I), 4$ as2 -CN ( $A, B, C, D), 12 \beta-C N(A 1, A 2, A 3, B, C$, $D, E, F, G, H 1, H 2, I), 14 \kappa-C N(A, A 1, B, B 2, C, D, E, F 1, F 2$, G1, G2, H, I, J), $11 \beta-L G(A, B, C, D, E, F, G, H, I, J, W)$ and $3 \alpha$-LA ( A, B, C), modified from Farrell et al. (2004) have been reported.
'Division of Animal Genetics and Breeding, Faculty of Veterinary Sciences and Animal Husbandry, Shuhama, Ganderbal-190 006, Jammu and Kashmir, India.

2Planning and Monitoring, Sher-e-Kashmir University of Agricultural Sciences and Technology of Kashmir, Shuhama, Alusteng, Srinagar-190 001, Jammu and Kashmir, India.

${ }^{3}$ KVK Nyoma, Sher-e-Kashmir University of Agricultural Sciences and Technology of Kashmir, Shuhama, Alusteng, Srinagar-190 001, Jammu and Kashmir, India.

${ }^{4}$ Division of LPM, Faculty of Veterinary Sciences and Animal Husbandry, Shuhama, Ganderbal-190 006, Jammu and Kashmir, India.

${ }^{5}$ Department of Sheep Husbandry-Kashmir, Srinagar-190 001, Jammu and Kashmir, India.

Corresponding Author: Ambreen Hamadani, Division of Animal Genetics and Breeding, Faculty of Veterinary Sciences and Animal Husbandry, Shuhama, Ganderbal-190 006, Jammu and Kashmir, India. Email: escritor005@gmail.com

How to cite this article: Shah, R.M., Ganai, N.A., Sheikh, F.D., Khan, H.M., Shanaz, S., Alam, S., Khan, N.N., Shabir, M., Bukhari, S., Hamadani, A., Rather, M.A. (2021). Effects of Beta-lactoglobulin Gene Polymorphism and Some Factors on Milk Quality and Yield in Dairy Cattle of Kashmir, India. Asian Journal of Dairy and Food Research. DOI: 10.18805/ajdfr.DR-1700.

Submitted: 26-04-2021 Accepted: 23-08-2021 Online: 17-09-2021 
The different genetic variants of milk proteins differ from each other by only a few amino acid substitutions or deletions within the polypeptide chain (Eigel et al., 1984). Several studies have been carried out to determine the frequencies of genetic variants of milk proteins in different cattle breeds (Erhardt, 1996; Baranyi et al., 1996 and Caroli et al., 2004) and possible relationships between milk protein polymorphism and economically important production traits, milk com-position, and quality have been widely studied (Yasemin and Cengiz, 2006) due to the potential use of milk protein types as an aid to genetic selection. The discovery of beta-lactoglobulin ( $\beta-L G, L G B, B L G$ ) gene initiated the start of intensive investigations of the varied genotypes of this beta-lactoglobulin whey protein. Polymorphisms in candidate $\beta$-LG genes are associated with traits of economic importance in cows and are related to milk composition, quality, production as well as cheese-production, (Singh et al. 2004; Stipp et al. 2013 and Selvaggi et al. 2014). $\beta-L G$ represents almost $50 \%$ of whey protein and $12 \%$ of total dairy milk protein (Selvaggi et al. 2014). The betalactoglobulin gene, located on the chromosome 11, is 4723 bp long and has seven exons. This beta-lactoglobulin protein is made up of 162 amino acid residues with a mass of 18.429 $\mathrm{kDa}$. Till date 15 alleles have been identified for the gene under study (Matejicek et al. 2008). Out of these, A and B variants are the most frequent and have also been greatly investigated (Zaglool et al. 2016). Variant B has often been associated with milk quality and variant $A$ has been related to milk yield in Bovines (Tsiaras et al. 2005). Factors other than genetic polymorphism of proteins in milk e.g., seasonal differences (Lindmark-Mansson et al. 2003; Amenu et al. 2006) and breed (Arunvipas et al. 2003) also affect the yield and quality of milk in cattle. However, their associations with the genetic variants $\beta$-LG have not been researched in detail. Moreover, the information on association of $\beta$-LG exon IV polymorphism in crossbred $\mathrm{HF}$ cows of Kashmir remains rare. This crossbred HF breed (Local Kashmiri cattlex pure HF cows) was developed under livestock improvement programme. Crossbred HF and Jersey cows are extremely common in Kashmir and reared since years due to their better adaptability to agroclimatic conditions of Kashmir and high resistance to disease. The study was framed to investigate the effects of polymorphism in exon IV of $\beta-L G$ as well as some nongenetic factors in Jersey and Crossbred HF cows during four seasons of Kashmir, India.

\section{MATERIALS AND METHODS}

The study was undertaken on 120 dairy cows of two genetic groups Jersey and Crossbred HF cows (60 each) maintained at an organized farm Mountain Livestock Research Institute (MLRI) of Sher-e-Kashmir University of Agricultural Sciences and Technology-Kashmir. Kashmir is having four seasons; Spring (march-may), Summer (June-august), Autumn (septnov.) and Winter (dec-feb). All the four seasons for the year 2016-2017 were taken into consideration for association study. Daily records of milk as well as milk samples $(50 \mathrm{ml})$ were collected and analysed for quality making use of Speedy Lab Milk Auto-analyser. Analysis was done for fat, SNF, protein, density, lactose and ash. The quantity traits for the present study were total milk yield, protein yield and fat yield.

The blood sample $(10 \mathrm{ml})$ was collected from jugular vein of each animal in a $15-\mathrm{ml}$ sterile graduated polypropylene tubes containing EDTA (0.5 M, pH=8.0). Genomic DNA was isolated by standard phenol-chloroform extraction method (Sambrook and Russell, 2001). Quality and quantity assessment of the DNA were done by checking its absorbance using a spectrophotometer at $260 \mathrm{~mm}$ concentration and $260 / 280 \mathrm{~mm}$ for purity. Working dilution of extracted DNA was prepared for each sample at a concentration of $50 \mathrm{ng} / \mathrm{\mu l}$. Amplification of Exon IV (262 bp) was done using primer pairs; forward 5'GTCCTTGT GCTGGACACCGACTACA'3 and reverse 5'CAGGACACC GGCTCCCGGTATATGA 3' (Ron et al. 1994). For the Polymerase Chain Reaction (PCR) with a final reaction volume of $25 \mu \mathrm{l}, 200 \mu \mathrm{M}$ dNTP (each), $50 \mathrm{ng}$ primer (each), $1 \cup$ Taq DNA polymerase and 500 ng template DNA, 10X buffer containing $\mathrm{MgCl}_{2}$ were used. Amplification cycling conditions were $95^{\circ} \mathrm{C}$ (1 $\left.\mathrm{min}\right)$, thirty-four cycles for denaturation at $95^{\circ} \mathrm{C}(30 \mathrm{secs})$, annealing at $60^{\circ} \mathrm{C}$ (90 secs) and extension at $72^{\circ} \mathrm{C}$ for 2 mins and a final extension step at $72^{\circ} \mathrm{C}(5 \mathrm{~min})$. The $\mathrm{PCR}$ reaction products were electrophoresed on agarose gel (1.5\%) and ethidium bromide was used to detect the amplification success. The PCR products were digested with 5 units of BsuRI (Hae III) (Thermo Scientific) at $37^{\circ} \mathrm{C}$ for $1 \mathrm{~h}$. The restricted fragments were stained with ethidium bromide and analysed electrophoretically. Visualization of the digested products was done under ultra violet light on a transilluminator. The banding patterns were scored manually and gels was recorded in a Gel Documentation System.

The frequency of different genotypes and alleles were calculated by using Popgene 1.31 (Yeh et al. 1999). To analyse the Hardy-Weinberg equilibrium of the population software Popgene version=1.31 was used (Yeh et al. 1999). The following general linear model was used for obtaining the association followed by Tukey's test using SAS 9.3 statistical software.

$$
Y_{i j k L}=\mu+B_{j}+G_{k}+S_{L}+E_{i j k L}
$$

Where

$Y_{i j k L}$ is the observation of $i^{\text {th }}$ animal of $j^{\text {th }}$ breed with $k^{\text {th }}$ genotype and $L^{\text {th }}$ season. $Y_{i j k L}$ is the milk yield/fat yield/ protein yield/ SNF/density/ash/lactose, $\mu$ the overall mean, Bj equals Jersey and Crossbred HF cows, Gk is genotypes for selected gene, $S_{L}$ is the season and $E_{i j k L}$ is the random error.

\section{RESULTS AND DISCUSSION PCR amplification and polymorphism analysis}

Both the breeds showed a single specific band of $262 \mathrm{bp}$ (Fig 1). Normally on digestion with Hae II/ restriction enzyme 
three patterns AA (153/109), AB (153/109/79/74) and BB $(109 / 79 / 74)$ have been reported but in present study, pattern of two bands 153/109 AA genotype and four bands 153/ 109/79/74 AB genotype were observed. The bands 79/74 could not be separated thus appeared as a single thick band (Fig 2). Genotype "BB" was absent. These findings were in

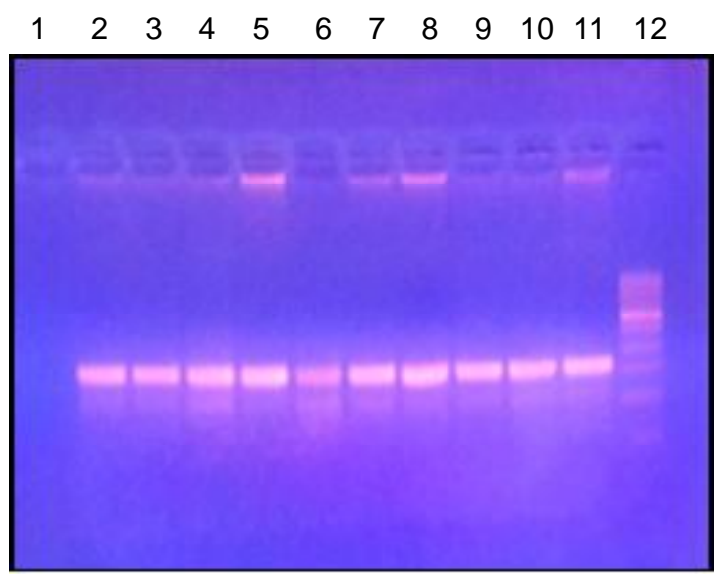

Fig 1: PCR amplification of exon IV Beta-Lactoglobulin ( $\beta-L G)$ gene: $262 \mathrm{bp}$.

Lanes 1-6: Jersey cows; Lanes 7-11: crossbred HF cows; Lane 12: $100 \mathrm{bp}$ marker.

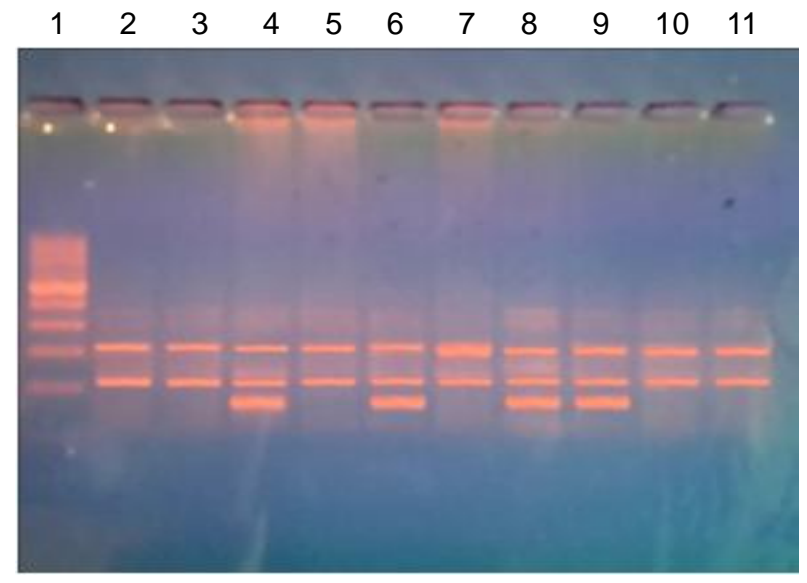

Fig 2: Polymorphisms of $\beta$-LG gene with BsuRI (Hae III) restriction enzyme.

Four bands: 153/109/79/74 AB genotypes; Two bands: 153/109 AA genotype.

Lanes 1: 100bp marker.

Lanes 2-6: Crossbred HF cows.

Lane 7-11: Jersey cows. not in agreement with studies of Aschaffenburg, 1964; Ivana and Marco, 1997; Litwinczuk and Krol, 2002; Celik, 2003; Yasmin and Cengiz, 2006; Daniela et al., 2008; Karimi et al., 2009; Heidari et al., 2009 and Lucak et al., 2013 who found all the three genotypes in their respective studied breeds. The presence of only two genotypes may be due the small sample size because MLRI is the only organized cattle farm in Kashmir under temperate conditions which limits the scope for increasing the population size for the study.

\section{Gene and genotype frequencies}

The present study showed higher frequency of AA genotype in both the Jersey cows (0.68) and crossbred HF cows (0.56) with higher frequency of A allele in Jersey cows (0.66) and Crossbred HF cows (0.72) (Table 1). Similar results were reported by Aschaffenburg, 1964; Ivana and Marco, 1997; Litwinczuk and Krol, 2002; Celik, 2003; Yasmin and Cengiz, 2006; Daniela et al., 2008 in B. taurus and B. indicus breeds. Our findings were in contrast with $\mathrm{Ng}$ Kwai-Hang et al. (1986), Van Eenennaam and Medrano, (1991), Celik (2003), Oner and Elmaci (2006) reporting the higher frequencies for $\mathrm{B}$ allele in Holstein cows. Present results were deviating from the findings among bovine breeds showing an improved prevalence for the B gene (Neves et al. 1998 and Faria et al. 2000) and better frequency for the BB genotype. Present findings indicated that allelic frequencies are in Hardy Weinberg equilibrium $(p<0.05)$ which suggests that animals are under no recent selection pressure for any of the alleles. Lucak et al. (2013) reported similar findings for the Serbian Holstein Friesian cattle that beta-Lactoglobulin locus fitted with Hardy-Weinberg equilibrium $(P<0.05)$, and was almost like that demonstrated by Gouda et al. (2011) in Egyptian Holstein cattle and Ren et al. (2011) in Chinese Holstein and Jersey cows.

\section{Association studies}

Effect of breed, season and genotype were found to be statistically significant for all yield traits $(p<0.05)$. The genotype $A B$ was found to be responsible for average monthly MY, PY and $F Y$ in each season in Jersey cows whereas it was genotype AA of crossbred HF cows affecting MY, PY and FY (Table 2). Crossbred HF cows, genotype effect was found to be non-significant $(p>0.05)$ on all quality traits and season was found to be effective for lactose and fat (Table 3). Genotype and season effects were found to be significant $(P<0.05)$ only on fat \% in Jersey cows (Table 4$)$. There are also reports for the positive influence on the milk

Table 1: Genotypic and allelic frequencies in Crossbred and Jersey cows.

\begin{tabular}{lccccc}
\hline Gene & Genotype & Frequency & Allele & Frequency & Chi-square \\
\hline$\beta$-LG & & & & & \\
Crossbred & AA & 0.56 & A & 0.72 & 0.032 \\
& AB & 0.44 & B & 0.28 & 0.002 \\
Jersey & AA & 0.68 & A & 0.66 & P \\
& AB & 0.32 & B & $0.05 ; N S$ \\
\hline
\end{tabular}


quantity of all the genotypes, for example, Pupkova, (1980) and Cardak, (2005) reported that cows having $A B$ genotype produce more milk than cows of $A A$ and $B B$ genotypes, however, Bovenhuis et al. (1992) and Ikonen et al. (2001) observed the rare beta lactoglobulin genotype AA was associated with the highest milk production. Similar results describing effects of the beta lactoglobulin genotypes on milk production traits that were observed (lkonen et al., 2001) and have been frequently reported ( $\mathrm{Ng}$-Kwai-Hang et al.,
1984; 1990; Mao et al., 1992). Heidari et al. (2009) reported that cows with the AA genotype produced more milk than animals with the $B B$ genotype $(P<0.006)$. Contrary to these findings, Hirstov et al. (2013) showed that the BB genotype determines higher milk production. Ahmadi et al. (2008) reported strong association between $B B$ genotype and protein percentage while there was no association between beta-Lactoglobulin genotypes and milk yield or milk fat percent.

Table 2: Effect of season, breed and BLG genotype on milk yield traits.

\begin{tabular}{|c|c|c|c|c|c|}
\hline Season & Breed & Genotype & Av. milk yield (MY) $\mathrm{Kg}$ & Av. protein yield (PY) kg & Av. fat yield $(F Y) \mathrm{kg}$ \\
\hline \multirow[t]{4}{*}{ Spring } & Crossbred & $A A$ & $223.11 \pm 10.18^{a}$ & $0.63 \pm 0.13^{a}$ & $0.80 \pm 0.02^{\mathrm{a}}$ \\
\hline & & $A B$ & $160.63 \pm 10.18^{b}$ & $0.48 \pm 0.12^{b}$ & $0.67 \pm 0.08^{b}$ \\
\hline & Jersey & $A A$ & $134.16 \pm 09.11^{\mathrm{b}}$ & $0.62 \pm 0.19^{b}$ & $0.92 \pm 0.03^{b}$ \\
\hline & & $A B$ & $263.15 \pm 09.08^{a}$ & $0.80 \pm 0.12^{\mathrm{a}}$ & $1.42 \pm 0.01^{\mathrm{a}}$ \\
\hline \multirow[t]{4}{*}{ Summer } & Crossbred & $A A$ & $295.02 \pm 11.18^{a}$ & $1.00 \pm 0.16^{a}$ & $0.96 \pm 0.07^{\mathrm{a}}$ \\
\hline & & $A B$ & $222.06 \pm 10.18^{b}$ & $0.87 \pm 0.12^{b}$ & $0.78 \pm 0.05^{b}$ \\
\hline & Jersey & $A A$ & $235.14 \pm 10.12^{b}$ & $0.98 \pm 0.16^{b}$ & $0.98 \pm 0.24^{b}$ \\
\hline & & $A B$ & $315.12 \pm 10.01^{\mathrm{a}}$ & $1.00 \pm 0.12^{\mathrm{a}}$ & $1.21 \pm 0.26^{\mathrm{a}}$ \\
\hline \multirow[t]{4}{*}{ Autumn } & Crossbred & $A A$ & $210.17 \pm 10.08^{a}$ & $0.90 \pm 0.11^{\mathrm{a}}$ & $0.95 \pm 0.01^{\mathrm{a}}$ \\
\hline & & $A B$ & $114.12 \pm 10.03^{b}$ & $0.68 \pm 0.12^{b}$ & $0.69 \pm 0.06^{b}$ \\
\hline & Jersey & $\mathrm{AA}$ & $132.12 \pm 11.01^{b}$ & $0.76 \pm 0.14^{b}$ & $0.98 \pm 0.11^{b}$ \\
\hline & & $A B$ & $256.15 \pm 11.03^{\mathrm{a}}$ & $0.98 \pm 0.13^{a}$ & $1.23 \pm 0.18^{a}$ \\
\hline \multirow[t]{4}{*}{ Winter } & Crossbred & $\mathrm{AA}$ & $145.14 \pm 11.12^{a}$ & $0.56 \pm 0.02^{\mathrm{a}}$ & $0.72 \pm 0.18^{a}$ \\
\hline & & $A B$ & $110.12 \pm 11.16^{b}$ & $0.39 \pm 0.12^{b}$ & $0.56 \pm 0.13^{b}$ \\
\hline & Jersey & $\mathrm{AA}$ & $123.16 \pm 11.12^{b}$ & $0.54 \pm 0.19^{b}$ & $1.01 \pm 0.13^{b}$ \\
\hline & & $A B$ & $163.13 \pm 11.18^{a}$ & $0.78 \pm 0.18^{a}$ & $1.18 \pm 0.11^{\mathrm{a}}$ \\
\hline
\end{tabular}

NS: Non-significant. ${ }^{a, b}$ Means with same superscripts are not significantly different $(P<0.05)$ from one another.

Table 3: Effect of BLG genotype and season on milk quality traits in Crossbred cows.

\begin{tabular}{|c|c|c|c|c|c|c|}
\hline Parameters & Protein (\%) & Lactose (\%) & Fat (\%) & SNF (\%) & Density & Ash (\%) \\
\hline \multicolumn{7}{|l|}{ Genotype } \\
\hline AA & $3.15 \pm 0.01^{\mathrm{NS}}$ & $4.45 \pm 0.04^{\mathrm{NS}}$ & $4.75 \pm 0.24^{\mathrm{NS}}$ & $8.51 \pm 0.00^{N S}$ & $26.83 \pm 0.19^{N S}$ & $0.69 \pm 0.00^{\mathrm{NS}}$ \\
\hline$A B$ & $3.16 \pm 0.01$ & $4.46 \pm 0.03$ & $4.73 \pm 0.25$ & $8.58 \pm 0.00$ & $27.17 \pm 0.15$ & $0.69 \pm 0.00$ \\
\hline \multicolumn{7}{|l|}{ Season } \\
\hline Winter & $3.15 \pm 0.00$ NS & $4.43 \pm 0.02^{b}$ & $4.89 \pm 0.11^{\mathrm{a}}$ & $8.53 \pm 0.12^{\mathrm{NS}}$ & $26.84 \pm 0.13^{\mathrm{NS}}$ & $0.69 \pm 0.00^{\mathrm{NS}}$ \\
\hline Spring & $3.16 \pm 0.01$ & $4.47 \pm 0.01^{a}$ & $3.66 \pm 0.13^{b}$ & $8.57 \pm 0.15$ & $27.15 \pm 0.15$ & $0.69 \pm 0.00$ \\
\hline Summer & $3.15 \pm 0.00$ & $4.47 \pm 0.01^{a}$ & $3.66 \pm 0.13^{b}$ & $8.53 \pm 0.12$ & $26.84 \pm 0.13$ & $0.69 \pm 0.00$ \\
\hline Autumn & $3.16 \pm 0.01$ & $4.43 \pm 0.02^{b}$ & $4.82 \pm 0.11^{\mathrm{a}}$ & $8.57 \pm 0.15$ & $27.15 \pm 0.15$ & $0.69 \pm 0.00$ \\
\hline
\end{tabular}

NS: Non-significant. a,bMeans with same superscripts are not significantly different $(P<0.05)$ from one another.

Table 4: Effect of BLG genotype and season on milk quality traits in Jersey cows.

\begin{tabular}{|c|c|c|c|c|c|c|}
\hline Parameters & Protein (\%) & Lactose (\%) & Fat $(\%)$ & SNF (\%) & Density & Ash (\%) \\
\hline \multicolumn{7}{|l|}{ Genotype } \\
\hline AA & $3.10 \pm 0.01^{\mathrm{NS}}$ & $4.36 \pm 0.02$ NS & $5.50 \pm 0.11^{\mathrm{a}}$ & $8.38 \pm 0.13^{\mathrm{NS}}$ & $26.83 \pm 0.19^{N S}$ & $0.68 \pm 0.01^{\mathrm{NS}}$ \\
\hline$A B$ & $3.07 \pm 0.01$ & $4.35 \pm 0.06$ & $4.90 \pm 0.13^{b}$ & $8.42 \pm 0.15$ & $26.36 \pm 0.15$ & $0.68 \pm 0.01$ \\
\hline \multicolumn{7}{|l|}{ Season } \\
\hline Winter & $3.07 \pm 0.00 \mathrm{NS}$ & $4.35 \pm 0.02^{\mathrm{NS}}$ & $5.31 \pm 0.11^{\mathrm{a}}$ & $8.38 \pm 0.19^{\mathrm{NS}}$ & $26.17 \pm 0.13^{N S}$ & $0.68 \pm 0.01^{\mathrm{NS}}$ \\
\hline Spring & $3.10 \pm 0.01$ & $4.36 \pm 0.03$ & $4.09 \pm 0.13^{b}$ & $8.42 \pm 0.15$ & $26.03 \pm 0.15$ & $0.68 \pm 0.01$ \\
\hline Summer & $3.07 \pm 0.00$ & $4.35 \pm 0.02$ & $4.09 \pm 0.13^{b}$ & $8.38 \pm 0.19$ & $26.17 \pm 0.13$ & $0.68 \pm 0.01$ \\
\hline Autumn ' & $3.10 \pm 0.01$ & $4.36 \pm 0.03$ & $5.31 \pm 0.11^{\mathrm{a}}$ & $8.42 \pm 0.15$ & $26.03 \pm 0.15$ & $0.68 \pm 0.01$ \\
\hline
\end{tabular}

NS: Non-significant. ${ }^{a, b}$ Means with same superscripts are not significantly different $(P<0.05)$ from one another. 


\section{CONCLUSION}

The populations of Crossbred HF and Jersey cattle were polymorphic and a allele was more commonly found. Based on the study it is concluded that the effects of breed, season and genotype of beta-lactoglobulin gene are highly correlated with milk quality and higher milk yield in the dairy cattle of Kashmir.

\section{ACKNOWLEDGEMENT}

The authors are thankful to In-charge, MLRI, Manasbal for providing data and animals for blood collection. Authors are also thankful to the Head, Division of Animal Biotechnology, FVSc and $\mathrm{AH}$, Shuhama for providing support in analysing milk samples.

\section{REFERENCES}

Ahmadi, M., Muhammadi, Y., Damani-Kuhi, H., Osfoori, R. and Qanbari, R. (2008). Association between milk protein genotypes and production traits and somatic cell count in Holstein cows. Journal of Biology Science. 8(7): 12311235.

Amenu, B., Cowan, T., Deeth, H. and Moss, R. (2006). Impacts of feeding system and season on milk composition and cheddar cheese yield in a subtropical environment. Australian Journal of Experimental Agriculture. 46: 299-306.

Arunvipas, P., Dohoo, I.R., Van Leeuwen, J.A. and Keefe, G.P. (2003). The effect of non-nutritional factors on milk urea nitrogen levels in dairy cows in Prince Edward Island, Canada. Preventive Veterinary Medicine. 59: 83-93.

Aschaffenburg, R. (1964). Protein phenotyping by direct polyacrylamide gel electrophoresis of whole milk. Biochemical Bio Physiology Acta. 82(1): 188-191.

Bovenhuis, H., Johan, A.M., Arendonk, V. and Korver, S. (1992). Associations between milk protein polymorphisms and milk production traits. Journal of Dairy Science. 75: 25492559.

Baranyi, M. and Bosze, Z.S. (1996). Genetic polymorphism of milk proteins in hungarian spotted and hungarian grey cattle: A possible new genetic variant of $\beta$-Lactoglobulin. Journal of Dairy Science. 7(2): 630-636.

Çardak, A.D. (2005). Effects of genetic variants in milk protein on yield and composition of milk from Holstein-Friesian and simmentaler cows. South African Journal of Animal Science. 35(1): 41-47.

Caroli, A.M., Chessa, S., Erhardt, G.J. (2009). Invited review: Milk protein polymorphisms in cattle: Effect on animal breeding and human nutrition. Journal of Dairy Science. 92: 53355352.

Celik, S. (2003). B-lactoglobulin genetic variants in Brown Swiss breed and its association with compositional properties and rennet clotting time of milk. International Dairy Journal. 13: 727-731

D'Alessandro, A., Zolla, L., Scaloni, A. (2011). The bovine milk proteome: Cherishing, nourishing and fostering molecular complexity: An interactomics and functional overview. Molecular Biosyst. 7: 579-597.
Daniela, I., Salajeanu, A., Magdin, A., Stanca, C. and Vintila, I. (2008). Genetic polymorphism at the $\beta$-lactoglobulin locus in a dairy herd of Romanian spotted and brown of Maramures. Animal Husbandry of Biotechnology. 41(1): 104-107.

Eigel, W.N., Butler, J.E., Ernstrom, C.A., Farrell, H.M., Halwarkar, V.R., Jenness, R. and Whitney, R.M. (1984). Nomenclature of proteins of cow's milk: Fifth revision. Journal of Dairy Science. 67: 1599-1631.

Erhardt, G. (1996). Detection of a new kappa-casein variant in milk of Pinzgauer cattle. Animal Genetics. 27: 105-107.

Farrell, H.M., Jr Jimenez-Flores, R., Bleck, G.T., Brown, E.M., Butler, J.E and Creamer, L.K. (2004). Nomenclature of the proteins of cows' milk-sixth revision. Journal of Dairy Science. 87: 1641-1674.

Faria, F.J.C., Guimaraes, S.E.F., Mourao, G.B., Lima, R.M.G. and Pinheiro, L.E.L. (2000). Polymorphism analysis of $\beta$ lactoglobulin gene in Nellore cows and effects on weaning weight of the calves. Arquivo Brasileiro de Medicina Veterina'ria e Zootecnia. 52: 261-265.

Gouda, E.M., Galal, M.K., Wasfy, M.A. and Abdelaziz, S.A. (2011). Phenotypes, Genotypes and allele frequencies of $\beta$ lactoglobulin in Egyptian cattle and buffalo. Journal of Agricultural Science. 3: 203-210.

Heidari, M., Azari, M.A., Hasani, S., Khan, A. and Zerehdaran, S. (2009). Association of genetic variants of $\beta$-lactoglobulin gene with milk production in a herd and a superior family of Holstein cattle. Iranian Journal of Biotechnology. 7(4): 254-257.

Hristov, P., Teofanova, D., Mehandzhiyski, I., Zagorchev, L., Radoslavov, G. (2013). Significance of Milk protein genes polymorphism for Bulgarian Rhodopean cattle: Comparative studies. Biotechnology and Biotechnology eq. 27(2): 3659-3664.

Ikonen, T., Bovenhuis, H., Ojhala, M., Ruottinen, O. and George, M. (2001). Associations between casein haplotypes and first lactation milk production traits in Finnish Ayrshire cows. Journal of Dairy Science. 84(2): 507-514.

Ivana, T. and Marco, A. (1997). Milk protein polymorphisms in Brazilian zebu cattle. Brazillian Journal of Genetics. 20(4). https://doi.org/10.1590/S0100-84551997000400011.

Karimi, K., Beigi-Nassiri, M.T., Mirzadeh, K.H., Ashayerizadeh, A., Roushanfekr, H., Fayyazi, J. (2009). Polymorphism of the $\beta$ - lactoglobulin gene and its association with milk production traits in Iranian Najdi cattle. International Journal of Biotechnology. 7(2): 82-85.

Lindmark-Mansson, H., Fonden, R. and Pettersson, H. (2003). Composition of Swedish dairy milk. International Dairy Journal. 13: 409-425.

Litwinczuk, Z. and Krol, J. (2002). Polymorphism of main milk proteins in beef cattle maintained in east central Poland. Animal Science Papers Reports. 20(1): 33-40.

Lucak, D., Vidović, V., Nemes, Z., Stupar, M. and Popovic-Vranjes, A. (2013). Genotypic frequencies of the $\beta$-lactoglobulin, $\kappa$-casein and transferrin in Serbian Holstein-Friesian dairy cattle. Mljekarstvo. 63(4): 203-210.

Mao, I.L., Buttazzoni, L.G. and Aleandri, R. (1992). Effects of polymorphic milk protein genes on milk yield and composition traits in Holstein cattle. Acta Agric. Scand. 42: 1-7. 
Matejicek, A., Matejickova, J. and Stipkova, M. (2008). Joint effects of CSN3 and LGB genes on milk quality and coagulation properties in Czech Fleckvieh. Czech Academy of Agriculture and Sciences. 53(6): 246-252.

Nilsen, H., Olsen, H.G., Hayes, B., Sehested, E., Svendsen, M., Nome, T., Meuwissen, T. and Lien, S. (2009). Casein haplotypes and their association with milk production traits in Norwegian Red cattle. Genet. Sel. Evol. 41: 24. DOI: 10.1186/1297-9686-41-24.

Neves, A.L.G., Guimaraes, S.E.F., Lima, R.M.G., Penna, V.M. and Pinheiro, L.E.L. (1998). Identification of $A$ and $B$ variants of the b-lactoglobulin gene in Brazilian Gir populations. Arquivo Brasileiro de Medicina Veterinaria e Zootecnia. 50: 409-414.

Ng-Kwai-Hang, K.F., Hayes, J.F., Moxley, J.E. and Monardes, H.G. (1984). Association of genetic variants of casein and milk serum proteins with milk, fat and protein production by dairy cattle. Journal of Dairy Science. 67: 835-840.

Ng-Kwai-Hang, K.F., Hayes, J.F., Moxley, J.E., Monardes, H.G. (1986). Relationships between milk protein polymorphisms and major milk constituents in Holstein-Friesian cows. Journal of Dairy Science. 69: 22-26.

Ng-Kwai-Hang, K.F., Monardes, H.G., Hayes, J.F. (1990). Association between genetic polymorphism of milk proteins and production traits during three lactations. Journal of Dairy Science. 73: 3414-3420.

Oner, Y. and Elmaci, C. (2006). Milk protein polymorphisms in Holstein cattle. International Journal of Dairy Technology. 59: 180-182.

Pupkova, G.V. (1980). Milk protein polymorphism and milk production of Estonian Black Pied cows. Dairy Science. 45: 6620.

Reinhardt, T.A., Lippolis, J.D., Nonnecke, B.J., Sacco, R.E. (2012). Bovine milk exosome proteome. J. Protem. 75(5): 1486-92.

Ren, D.X., Miao, S.Y., Chen, Y.L., Zou, C.X., Liang, X.W. and Liu, J.X. (2011). Genotyping of the $\kappa$-casein and $\beta$-lactoglobulin genes in Chinese Holstein, Jersey and water buffalo by PCR-RFLP. Journal of Genetics. 90(1): 1-5.
Ron, M., Yofee, O., Ezra, E., Medrano, J.F. and Weller, J.I. (1994). Determination of effects of milk protein genotype on production of Israeli holstein. Journal of Dairy Science. 77: 1106-1113.

Sambrook, J.F. and Russell, D.W. (2001). Molecular Cloning. A Laboratory Manual. $3^{\text {rd }}$ edition. Vol 1 Cold Spring Harbor Laboratory Press. pp 2100.

Selvaggi, M., Laudadio, V., Dario, C. and Tufarelli, V. (2014). Investigating the genetic polymorphism of sheep milk proteins: A useful tool for dairy production. Journal of Science Food Agriculture. 94(15): 3090-3099.

Singh, H. (2004). Heat stability of milk. International Journal of Dairy Technology. 57: 111-119.

Stipp, A.T., Bignardi, P.R., Polifrederico, R.C., Sivieri, K. and Costa, M.K. (2013). Polimorfismos genéticos Da Kappa-Caseína E Da Betalactoglobulina E Produção De Leite Em Bovinos. Arquivo Brasileiro De Medicina Veterinária E Zootecnia. 65(1): 275-280.

Tsiaras, A.M., Bargouli, G.G., Banos, G. and Boscos, C.M. (2005). Effect of kappacasein and b-lactoglobulin loci on milk production traits and reproductive performance of Holstein cows. Journal of Dairy Science. 88: 327-334.

Van Eenennaam, A.L., Medrano, J.F. (1991). Differences in allelic protein expression in the milk of heterozygous $\kappa$-casein cows. Journal of Dairy Science. 74: 1491-1496.

Yasemin, O., Cengiz, E. (2006). Milk protein polymorphisms in Holstein cattle. International Journal of Dairy Technology. $5(3)$.

Yeh, F.C., Yang, R. and Boyle, T. (1999). POPGENE. Version 1.31. Microsoft Window-based Freeware for Population Genetic Analysis, University of Alberta. Edmonton, AB, Canada.

Zaglool, A.W., Awad, A., El, S., El, A., El-Bayom, K.M. (2016). Association of B-Lactoglobulin gene polymorphism with milk yield, fat and protein in holstein-friesian cattle. World. 6(3): 117-122. 